\title{
PRAWO PRACOWNICZESWOBIC
}

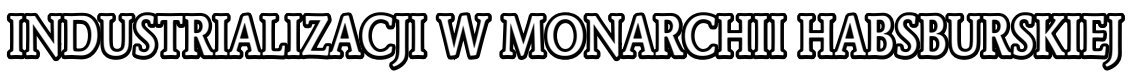

\section{Słowa kluczowe: Monarchia habsburska, prawo pracy}

Keywords: The Habsburg Monarchy, labour law

\begin{abstract}
The nineteenth century saw industrial modernisation, technological innovativeness and an increased demand for products in the Habsburg Monarchy. This brought about the development of the labourmarket The increase in the employment in the liberal economy and the related problems forced the authorities to introduce the regulations to control employment relationships. The article describes basic legal acts introduced into Austrian legislation until 1918.
\end{abstract}

Jednym z zasadniczych czynników modernizacji w XIX w. był szybko rozwijający się przemysł. W rozwoju liberalnej gospodarki siłą napędową była innowacyjność technologiczna, szczególnie w obszarze przemysłu metalowego, włókienniczego i górnictwa. Przemysł wpłynął w zasadniczym stopniu na rozwój miast, w których powstawały zakłady przemysłowe i szybko zwiększała się liczba ludności utrzymująca się z pracy najemnej. Rewolucja przemysłowa zmieniała strukturę zatrudnienia w gospodarce Anglii, Francji, Belgii i innych państw Europy Zachodniej. Poza sferą ekonomiczną miała wpływ na stosunki socjalne, politykę i kulturę. Mniej żywiołowo proces ten przebiegał na terenie Austrii. Monarchia habsburska należała do państw, w których procesy industrializacyjne nie przebiegały na dużą skalę, nie powodowały gruntownych przeobrażeń w zakresie stosunków gospodarczych. Do końca wielonarodowej monarchii gospodarka austriacka zachowała w znaczącym stopniu charakter agrarny, chociaż modernizacja struktur gospodarczych postępowała w okresie XIX w. 
U progu rewolucji przemysłowej, w 1770 r. na terenie Austrii właściwej działało 26 manufaktur (w tym w Austrii Dolnej 20), na Węgrzech (bez Siedmiogrodu) 19, w Czechach, na Morawach i Śląsku 32. W 1790 r. w monarchii habsburskiej znajdowało się 317 manufaktur i fabryk, z czego 180 na terenie krajów austriackich, 66 na Węgrzech. $Z$ tej liczby 84 z branży włókienniczej, a 34 zajmowało się produkcją stali i budową maszyn. W latach 1790-1825 nastąpiło zahamowanie rozwoju austriackiego przemysłu ze względu na wojny napoleońskie ${ }^{1}$. W pierwszym okresie industrializacji monarchii habsburskiej motorem napędowym były maszyny i urządzenia sprowadzone z zagranicy, przeważnie z Anglii. Już w 1802 r. wykorzystuje maszyny w fabryce włókienniczej w czeskim Blansku hrabia Hugo Salm. W fabryce sukna w Brnie na Morawach w 1814 r. pojawiły się udoskonalone maszyny parowe. W wiedeńskiej fabryce sukna Johanna Reissera takie maszyny pojawiły się w $1815 \mathrm{r}$. Władze państwowe wspierały rozwój inwestycji w zakresie nowych technologii. Dekret Kamery Nadwornej z 27 II 1827 r. wprowadzał ulgi podatkowe dla przedsiębiorców z racji nabycia nowoczesnych maszyn i urządzeń przemysłowych. Pierwszą dużą austriacką fabrykę maszyn uruchomił w 1832 r. w Pottenstein w Austrii Dolnej Melchior von Steiner. Po jego śmierci fabryka została zlikwidowana w $1841 \mathrm{r}$. W jej miejsce powstała fabryka włókiennicza. Należy podkreślić, że w latach 18411857 w części zachodniej monarchii habsburskiej nastąpił widoczny wzrost produkcji przemysłowej. Jako przykład ożywienia gospodarczego można podać prężnie działające w pierwszej połowie XIX w. niedaleko Wiednia największe w Europie przedsiębiorstwo produkujące cegły i dachówki, należące do Aloisa Miesbacha. W jego składzie było dziewięć cegielni, w których pracowało ponad 4700 osób. W ramach imperium gospodarczego Miesbacha działało także 30 kopalń z ponad 2300 górnikami. W 1848 r. w monarchii habsburskiej istniało 31 fabryk budujących urządzenia i maszyny przemysłowe z 3800 pracownikami. Dwadzieścia lat później takich fabryk było już 130. W połowie XIX w. ważnym czynnikiem prorozwojowym w gospodarce było przystąpienie Austrii do niemieckiego związku celnego, które służyło obrotowi towarów, ale też i inwestycjom kapitałowym. Zwiększenie wymiany handlowej oraz wzrost produkcji przemysłowej nie był trwały.

${ }^{1}$ G. Otruba, Österreichische Fabriksprivilegien vom 16. Bis ins 18. Jahrhundert und ausgewählte verwandte Quellen zur Frühgeschichte der Industrialisierung, Wien, Köln, Graz 1981, s. 33-38, 59. 
Rywalizacja o przywództwo w Związku Niemieckim zakończyła się niepowodzeniem Austrii po wojnie z Prusami w 1866 r. Następne lata to okres spowolnienia w rozwoju przemysłu na terenie monarchii habsburskiej². Gospodarka austriacka w drugiej połowie XIX w. i w pierwszych dziesięcioleciach XX w. rozwijała się wolniej niż gospodarki Anglii, Belgii, Szwajcarii, Niemiec, Francji czy Szwecji. Na terenie Przedlitawii obok ośrodków przemysłowych w Czechach, na Morawach i Śląsku, większe skupiska fabryczne powstały na terenie Austrii właściwej, między innymi w regionach Mur-Mürz-Furche w Styrii, następnie Wiener Becken w Austrii Górnej, w Basin w południowej Karyntii oraz w Vorarlbergu. Industrializacja wpłynęły na rozwój takich miast jak Wiedeń, Graz, Linz, Klagenfurt, a także Bregencji, Wiener Neustadt, Steyr czy Heinfeld.

Na przełomie XIX i XX w. rozwijał się przemysł naftowy w Zagłębiu Borysławsko-Drohobyckim w Galicji. Przyrost pracowników najemnych przemysłowych i handlowych w Galicji w okresie poprzedzającym wybuch pierwszej wojny światowej był bardziej dynamiczny i osiągnął stan 320 tysięcy. Z drugiej strony nasiliły się procesy migracyjne. W latach 1870-1914 Galicję opuściło ponad milion osób, głównie pochodzących ze wsi3 . Przed wybuchem pierwszej wojny światowej 56\% produkcji przemysłowej Przedlitawii wytwarzały Czechy i Morawy, kraje koronne Austrii właściwej dostarczały ok. 30\%, Galicja i Bukowina 9\%, zaś Dalmacja ok. 5\%, chociaż ostatnie trzy kraje koronne stanowiły $40 \%$ ogółu ludności ${ }^{4}$. W takiej sytuacji należy wskazać na podstawowy czynnik społeczny, który utrudniał postęp, jakim był brak wykształcenia szerszych kręgów społeczeństwa. Szczególną barierą rozwojową był analfabetyzm. W bardzo słabo rozwiniętej gospodarczo Dalmacji w 1900 roku umiejętnością czytania i pisania mogło się wykazać tylko 27\% mieszkańców. W dobrze rozwijającym się pod względem gospodarczym kraju koronnym Vorarlberg, 99\% społeczeństwa umiało pisać i czytać5. Kultura społeczna poszczególnych krajów koronnych monarchii habsburskiej była czynnikiem spowalniającym procesy modernizacyjne, jakie zachodziły

2 Szerzej zob.: T. F. Huertas, Economic Growth and Economic Policy in a Multinational Setting. The Habsburg Monarchy 1841-1865, New York 1977.

3 A. Korobowicz, Historia ustroju i prawa polskiego 1772-1918, Warszawa 2009, s. 203.

${ }^{4}$ R. Cameron, A New Viev of European Industrialization, The Economic History Reviev, nr 1 (1985), s. 16.

${ }^{5}$ Tamże. 
w obszarze gospodarki. Zjawiskiem, które wpływało na nierównomierny rozwój przemysłu była koncentracja kapitału inwestycyjnego w zachodniej części Przedlitawii. Stan ten nie uległ zasadniczej zmianie do końca istnienia monarchii. W 1913 r. najwyższy dochód na mieszkańca odnotowano w Austrii Dolnej wraz z Wiedniem (850 Kr), następnie kolejno w Czechach, na Morawach, Salzburgu, Austrii Dolnej, na Śląsku, w Krajnie, w Galicji, na Bukowinie i najmniejszy w Dalmacji $(264 \mathrm{Kr})^{6}$. Część węgierska monarchii habsburskiej była mniej uprzemysłowiona niż austriacka. Na terenie Cislitawii $75-80 \%$ ludności pracowało $\mathrm{w}$ rolnictwie. W przemyśle zatrudnionych było $10 \%$ mieszkańców 7 .

W ostatnich latach przed wybuchem pierwszej wojny światowej w monarchii habsburskiej prawie cały przemysł był zorganizowany w ramach kilkudziesięciu karteli, które opanowały poszczególne jego sektory i miały swoje siedziby w Wiedniu. Działały one w obszarze produkcji stali i gotowych wyrobów żelaznych, przędzalniczo-tkackim, chemicznym, papierowym, spirytusowym, cukrowym, piwnym, krochmalno-słodowym, skórzanym, materiałów budowlanych, szklarsko-ceramicznym. Poszczególne kartele prowadziły własną politykę w zakresie produkcji, cen i warunków sprzedaży, poprzez regionalne sieci sprzedaży. Działały w porozumieniu z kartelami węgierskimi i niemieckimi, wpływając na oficjalną politykę handlową Austrii. W drodze umów ograniczały lub rozszerzały obrót towarów przemysłowych, tworząc obok istniejących traktatów handlowych i taryf celnych ${ }^{8}$. Niemniej należy wskazać na fakt, że rynek węgierski zamykał się przed towarami z Przedlitawii, dlatego przemysł działający głównie w zachodnioaustriackich krajach koronnych, ramach rynku wewnętrznego szukał zbytu między innymi w Galicji i na Bukowinie. Dlatego każdy powstający zakład przemysłowy we wschodnich krajach koronnych stanowił dla austriackich karteli uszczuplenie rynku zbytu. Inicjatywy podejmowane w zakresie rozwoju produkcji przemysłowej głównie w Galicji były przez wiedeńskie kartele zwalczane. I chociaż w okresie pierwszej wojny światowej kartele zostały rozwiązane

${ }^{6}$ P. Eigner, Die Habsburgermonarchie im 19. Jahrhundert. Ein Modellfall verzögerter Industrialisierung?, Beiträge zur historischen Sozialkunde, nr 3, (1997), vgs.univie.ac.at/ VGS_alt/b973lp.html (data dostępu: 15.06.2013)

7 F. Szávai, The Late industrial revolutionin Hungary (1867-1918), [in:] Hungary and the Hungarians, red. S.J. Magyaródy, b. m. w. (USA) 2012, s. 247.

8 A. Benis, Przemysł galicyjski a Austria, Kraków 1917, s. 10-13. 
$\mathrm{i} \mathrm{w}$ to miejsce zostały utworzone wiedeńskie centrale towarowe i wojenne związki produkcyjne, to nadal były one kontynuatorem przedwojennych praktyk monopolistycznych na rynku zbytu. Towarzyszyła temu także polityka banków austriackich i czeskich, które wspierały działania przedsiębiorstw z zachodnich krajów koronnych. Na terenie Galicji większe środki przeznaczały głównie na zwiększenie wydobycia ropy naftowej lub pozyskanie drewna. Bank Krajowy od 1883 r. zaczął finansować działalność przemysłową, a od 1887 r. Fundusz Przemysłowy, który był zasilany główne ze środków krajowych. Od 1908 r. zaczął działać Fundusz Inwestycyjny, który w 1911 r. dysponował kwotą 1,5 miliona Kr. W 1911 r. powstał we Lwowie Bank Przemysłowy, który otworzył filię w Krakowie. Podejmowane działania w zakresie kapitałowym nie stanowiły poważniejszej konkurencji dla kapitału zewnętrznego9. Dlatego w Galicji w przemyśle chemicznym, metalurgicznym czy w górnictwie, większą aktywność wykazywał kapitał pochodzący z niemieckiego Śląska, Berlina czy Frankfurtu nad Menem, niż z Wiednia. Znaczącą pozycję miał też kapitał francuski.

Rozwój przemysłu w ramach liberalnych stosunków gospodarczych rozbudził duże zapotrzebowanie na siłę roboczą. Stosunki fabryczne charakteryzujące się koncentracją kapitału, dążeniem do maksymalizacji zysku, organizacją produkcji często opartej na systemie zmianowym powodowały określone problemy w zakresie spraw pracowniczych. W ramach stosunków pracy dotychczasowe normy oparte o zwyczaj były często nieprzestrzegane. W sytuacji kiedy zakłady przemysłowe rozwijały się dynamicznie, zatrudniając dużą liczbę pracowników przy dowolności kształtowania stosunków pracy, potrzebne były nowe regulacje. Państwa europejskie w ramach ustawodawstwa fabrycznego zmuszone były stopniowo wprowadzać normy prawne adresowane dla pracodawców. W ramach prawa publicznego ustawodawca zaczął stosować zasadę ochrony uprawnień robotników przemysłowych w oparciu o automatyzm prawny, przy poszanowaniu zasad swobodnego nawiązania i zerwania stosunku pracy. Naturalnie stanowione nakazy i zakazy odnosiły się do pracy najemnej. W dziewiętnastowiecznym liberalizmie ekonomicznym dominowała nierówność stron umowy najmu pracy. Przedsiębiorca dążąc do maksymalizacji zysku, eksploatował w znacznym stopniu robotnika. W myśl obowiązującej doktryny, przedmiotem umowy najmu

9 K. Bartoszewicz, Dzieje Galicji. Jej stan przed wojnq i „wyodrębnienie”, Kraków 1917, s. $193-194$. 
pracy w gospodarce była siła fizyczna w zamian za pieniądze, czasem dobra w naturze. W przypadku dziedzicznych krajów monarchii habsburskiej $\mathrm{w}$ dobie industrializacji sprawę umów najmu pracy regulował kodeks cywilny z 1811 r. $(A B G B)^{10}$. W części II „o prawach rzeczy osobistych”, w rozdziale XVII „o umowach (kontraktach) w ogólności”, paragraf 861 stwierdzał, że „kto się oświadcza, iż prawo swoje chce na kogoś przenieść, iż to jest że mu chce coś dozwolić, coś dać, że dla niego coś chce uczynić ten robi obietnice, gdy zaś drugi tę obietnicę ważnie przyjmuje, tędy na mocy jednomyślnej obydwóch stron woli, zawiera się układ, czyli kontrakt”. ABGB w paragrafie 883 podkreślał, że umowa mogła być zawarta słownie lub na piśmie. Przy czym ustawodawca zdając sobie sprawę, że w państwie żyje duża liczba osób niepiśmiennych, w paragrafie 886 podkreślał, iż „kto nie umie pisać, lub dla wad ciała pisać nie może, ten dwóch świadków, z których by jeden jego nazwisko podpisał, przybrać i zwykły znak swojej ręki, położyć powinien". ABGB regulował także sprawę umowy na czas określony w paragrafie 1160, który stwierdzał, że „robotnicy na czas oznaczony lub aż do ukończenia dzieła jakiego zamówieni, nie mogą bez prawnej przyczyny, ani porzucać roboty, ani być oddalonymi przed wyjściem czasu, lub przed ukończeniem dzieła. Jeżeli robota zostanie przerwana; każda strona odpowiada za swoje winę, a żadna za przypadek". Za wykonywane czynności należało się wynagrodzenie. Zwyczajowo wysokość wynagrodzenia podlegała negocjacji, niemniej w praktyce przedsiębiorcy narzucali swoim robotnikom bardzo niskie stawki. Szczególnie małe wynagrodzenia otrzymywały kobiety i dzieci. W przypadku osób nieletnich należy podkreślić, że zgodnie z paragrafem 152 ABGB podlegały one władzy rodzicielskiej i nie miały prawa zaciągać zobowiązań. Jednak należy przytoczyć paragraf 264, który głosił, że „jeżeli małoletni przyjął jaką służbę, opiekun nie może go bez ważnej przyczyny odwołać z takowej przed terminem, ustawą lub umową oznaczonym, chociażby to małoletni bez jego zezwolenia uczynił. Tem wszystkiem, co tym albo innym sposobem małoletni przez swoją pilność zarobi, tudzież rzeczami, które mu po dojrzałości do jego użytku oddane będą, może dowolnie rozporządzać i względnie tego

${ }^{10}$ Allgemeines Bürgerliches Gesetzbuch, www.ibiblio.org/ais/abgb1.htm (data dostępu: 16.06.2013). Księga ustaw cywilnych wszystkim niemiecko-dziedzicznym krajom Monarchii Austriackiej powszechna, Kraków 2011 (replint). Austriacki kodeks cywilny, www.pwsz.legnica.edu.pl/ siejam/ustawy/abgb.doc (data dostępu: 16.06.2013). M. Kallas, M. Krzymkowski, Historia ustroju i prawa w Polsce. Wybór źródeł, Warszawa 2006, s. 337-344. 
zobowiązania na siebie zaciągać". Zapis ten nie uległ zmianie przez ponad sto lat. Na mocy rozporządzenia cesarskiego z 19 III 1916 r., które nowelizowało $A B G B$, osoby nieletnie miały prawo na samodzielne zaciąganie zobowiązań w kwestii usług $\mathrm{w}$ drodze umowy bez zezwolenia opiekuna ${ }^{11}$.

Zasadnicze korzyści z pracy robotników czerpali przedsiębiorcy. W realiach ustrojowych Austrii i innych państw w XIX w. przedsiębiorca miał wsparcie w przymusie prawnym. Masowy wyzysk, wszechobecne ubóstwo i choroby w środowiskach robotniczych, wykorzystywanie do pracy dzieci budziło niezadowolenie i radykalizowało nastroje społeczne. W celu obrony ludzi pracy najemnej powstał i rozwijał się ruch związkowy, wreszcie polityczny nurt socjaldemokratyczny. Konserwatywne środowiska polityczne sprawujące władzę w państwach, żyjące w symbiozie z przedsiębiorcami, głównie z obawy o destabilizację porządku społecznego i prawnego zostały zmuszone przyjmować przepisy w zakresie stosunków pracy. W XIX w. prawo pracy funkcjonowało przeważnie $\mathrm{w}$ zakresie prawa administracyjnego, w ramach ustawodawstwa fabrycznego.

W powszechnej historii prawa, w zakresie dziewiętnastowiecznego ustawodawstwa fabrycznego, w którym pojawiły się elementy prawa pracy, w pierwszej kolejności należy wskazać na dorobek brytyjski. Przyjmowane przez parlament brytyjski akty prawne na początku XIX stulecia dotyczyły zatrudnienia dzieci oraz warunków higienicznych w zakładach przemysłowych. Ustawa z 1802 r. („The Health and Morals of Apprentices Act”) była reakcją na raport o dramatycznej sytuacji pracowników, w tym dzieci (tzw. praktykantów) pracujących w fabryce włókienniczej Roberta Peela w Radcliffe ${ }^{12}$. Na mocy ustawy między innymi został ograniczony czas pracy dzieci i młodzieży do 21 roku życia do 12 godzin dziennie. Przedsiębiorcy mieli

11 Dziennik Ustaw Państwa dla królestw i krajów w radzie państwa reprezentowanych (dalej: DzUP), 1916, nr 69. E. Till, Druga i trzecia nowela dla austriackiego kodeksu cywilnego z objaśnieniami na podstawie materiałów, Lwów 1916, s. 6.

${ }_{12}$ W 1784 r. w fabryce Roberta Peela wybuchła epidemia, która rozprzestrzeniła się na okoliczną ludność. Z raportu sporządzonego przez lekarza Thomasa Percivala wynikało, że robotnicy pracowali w bardzo trudnych warunkach. Raport zawierał szereg zaleceń, które miały poprawić higienę pracy. Między innymi powiększenie okien i zainstalowanie systemu wentylacji pomieszczeń, codzienne sprzątanie hal produkcyjnych, a raz w tygodniu mycie podłóg wodą z wapnem, przestrzeganie higieny osobistej przez pracowników, zwiększenie czasu na odpoczynek w trakcie pracy oraz zmniejszenie godzin pracy dzieci. A. Meiklejohn, Outbreak of Fever in Cotton Mills at Radcliffe 1784, British Journal of Industrial Medicine, nr 16 (1959), s. 68-69. 
obowiązek wyposażyć pracujące dzieci i młodzież w ubrania robocze oraz nauczyć czytać, pisać i liczyć w okresie pierwszych czterech lat pracy. We wszystkich zakładach przemysłowych miały być przestrzegany zasady higieny pracy i porządku. Miejscowe sądy miały obowiązek wyznaczyć dwóch inspektorów (jednym miał być duchowny, drugim sędzia pokoju), którzy mieli prawo dokonywać kontroli i egzekwowania przepisów zawartych w ustawie. W przypadku niewykonania nałożonego ustawą obowiązku, właściciela zakładów mogli karać grzywną ${ }^{13}$. W 1819 r. została przyjęta ustawa, na mocy której zakazano zatrudniania w przemyśle włókienniczym dzieci poniżej 9 roku życia. Kolejny brytyjski akt prawny z 1833 r. wprowadził zakaz pracy nocnej i maksymalny 12-godzinny dzień pracy dla młodzieży poniżej 18 lat. Kilka lat później wprowadzony został zakaz pracy dzieci i kobiet w kopalniach pod ziemią. Ustawodawstwo brytyjskie regulowało sprawy bezpieczeństwa i higieny pracy w przedsiębiorstwach. Władze brytyjskie w $1833 \mathrm{r}$. ustanowiły inspekcję pracy. Należy jednak podkreślić, że egzekucja przepisów w zakresie zatrudniania, bezpieczeństwa i higieny pracy napotykała na szereg trudności.

Na terenie państw niemieckich w wymiarze ogólnopaństwowym pierwszą regulację dotyczącą prawa pracy w przemyśle przeprowadziły Prusy. Było to rozporządzenie królewskiego departamentu stanu z 9 III 1839 r. o zatrudnianiu młodych pracowników w fabrykach („,die Beschäftigung jugendlicher Arbeiter in Fabriken"). W paragrafie 1 rozporządzenia zakazano zatrudnianie dzieci poniżej dziewiątego roku życia w zakładach produkcji maszyn, górnictwie, hutnictwie i młynach. Pracodawcy nie mieli prawa zatrudniać dzieci do 16 lat $\mathrm{w}$ niedziele i w nocy. Na mocy rozporządzenia na przedsiębiorców zatrudniających osoby poniżej 16 roku życia nałożono obowiązek zorganizowania im nauki czytania i pisania. Jednocześnie został ograniczony czas pracy młodzieży do 10 godzin ${ }^{14}$. W 1840 r. podobne przepisy zaczęły obowiązywać w Królestwie Bawarii i Wielkim Księstwie Badenii.

Habsburgowie austriaccy pewne zainteresowanie warunkami pracy w funkcjonujących manufakturach i tworzących się fabrykach wykazywali w okresie oświecenia. Cesarzowa Maria Teresa w 1768 r. w wydanych przepisach fabrycznych („Fabrikordnungen”) nakazała dbać o odpowiednie

\footnotetext{
${ }^{13}$ Early factory legislation, www.parlament.uk (data dostępu: 12.06.2013).

${ }^{14}$ Regulativ über die Beschäftigung jugendlicher Arbeiter in den Fabriken vom 9. März 1839, www. zeitspurensuche. de (data dostępu: 12.06.2013).
} 
warunki pracy dla dzieci i wypłacać im pieniądze za pracę. Była zaniepokojona złym stanem zdrowia młodych mężczyzn pracujących w trudnych warunkach na terenie Austrii Dolnej, którzy nie nadawali się do służby wojskowej. Dla nadzoru warunków pracy młodych osób w zakładach produkcyjnych Austrii Dolnej w 1772 r. ustanowiła odrębne stanowisko w wojsku. Syn Marii Teresy Józef II zainteresował się kwestią robotniczą, a szczególnie zatrudnianiem dzieci i młodzieży. Jednym z powodów były epidemie tyfusu, które dziesiątkowały pracowników fabrycznych w Austrii Dolnej. W odręcznym piśmie z 20 XI 1786 r. (tzw. „Allerhöchste Handbillett”), napisanym po wizycie w fabryce włókienniczej w Traiskirchen, w której pracowało 150 osób, w tym dużo dzieci, Józef II zwrócił się do hrabiego Antona Pergena, prezydenta rządu krajowego Austrii Dolnej o wprowadzenie ścisłego nadzoru administracyjnego starostwa powiatowego $\mathrm{w}$ Traiskirchen nad warunkami pracy w przedsiębiorstwach na terenie powiatu. W piśmie nakreślił warunki, jakie właściciele fabryk mieli spełnić, zatrudniając dzieci, aby nie podupadły na zdrowiu. Wśród nich należy wskazać na dozór w zakresie higieny osobistej czy wyposażenie dzieci we właściwe ubranie robocze ${ }^{15}$. W 1787 r. Józef II uznał, że w fabrykach nie powinny pracować dzieci poniżej dziewiątego roku życia ${ }^{16}$. W monarchii habsburskiej w 1842 r. został wprowadzony zakaz zatrudniania dzieci poniżej 12 roku życia, jednocześnie pracę młodzieży ograniczono $z 16$ do 12 godzin dziennie.

W celu egzekucji przepisów dotyczących bezpieczeństwa i higieny pracy na mocy dekretu dworskiego z 6 XI 1810 r. powstała cesarska inspekcja fabryczna, ale działała tylko do 1825 r. Na terenie Austrii Górnej w 1846 r. zaczął obowiązywać dekret rządu regionalnego („Landesregierung”), który określił minimalny wiek, uprawniający do pracy w zakładach przemysłowych na 12 lat. Młodzi wiekiem pracownicy nie powinni pracować dłużej niż 10 godzin dziennie. Zatrudnieni mieli przechodzić obowiązkowe badania lekarskie, a przedsiębiorstwa miały być poddane kontrolom trzy razy w roku przez niezapowiedziane komisje państwowe ${ }^{17}$. Wprowadzony zmniejszony czas pracy dla dzieci był trudny do egzekwowania, gdyż przeważnie pracowały one w zespołach wraz z dorosłymi. Osoby dorosłe obowiązywał

15125 Jahre Arbeitsinspektion in Österreich. Die Arbeitsinspektion im Wandel der Zeit, Wien 2009, s. 13.

16 Vorgeschichte, www.arbeitsinspektion.gv.at (data dostępu: 14.06.2013)

17125 Jahre Arbeitsinspektion in Österreich, s. 14-15. 
nadal 16-godzinny dzień pracy. Opór przedsiębiorców był na tyle stanowczy, że władze Austrii Górnej po kilku miesiącach zostały zmuszone do uchylenia przepisów. Problem miał też i drugie dno, mniej godzin pracy, to także mniejsze zarobki. Często rodzice nie chcieli zrezygnować z zarobków swoich dzieci, które i tak były bardzo skromne. Należy także wskazać na wysoki poziom bezrobocia, jaki panował w XIX-wiecznej Austrii. „Rezerwowa armia przemysłowa" czekała pod bramą przedsiębiorstw. Rezultatem takiego stanu było zjawisko obniżania płac i długi dzień pracy. Sytuacja przybrała dramatyczny obrót w czasie wydarzeń marcowych w 1848 r., podczas których robotnicy i bezrobotni na przedmieściach Wiednia niszczyli maszyny i podpalali budynki fabryczne. W konsekwencji 15 VII 1848 r. introligator Friedrich Sander w budynku Josefstädter Theater zakłada pierwsze w Wiedniu Stowarzyszenie Robotników, które było zalążkiem austriackiego ruchu związkowego. Protest zorganizowany przez Sandera w sierpniu 1848 r. przeciwko obniżaniu płac został krwawo stłumiony, zaś stowarzyszenie władze rozwiązały.

W dobie politycznego centralizmu (neoabsolutyzmu) została podjęta inicjatywa prawodawcza w zakresie stosunków pracy, w ramach ogólnej regulacji dotyczącej działalności gospodarczej w monarchii habsburskiej. Efektem tego była ustawa przemysłowa („Gewerbeordnung”) wprowadzona patentem cesarskim z 20 XII 1859 r. $^{18}$, która zaczęła obowiązywać na terenie całego państwa od 1 V 1860 r. Należy jednak podkreślić, że stosunki prawne pomiędzy przedsiębiorcami (pracodawcami) a tzw. służbą pomocniczą (pomocnicy i uczniowie - służbobiorcy) nadal regulował ABGB z 1811 r., o czym wspomniano już powyżej. Ustawa przemysłowa zawierała szereg postanowień uzupełniających. Zgodnie $z$ duchem liberalizmu gospodarczego w zakresie ogólnych stosunków gospodarczych w monarchii habsburskiej ustawa przemysłowa z 20 XII 1859 r. utrzymała instytucję rejestracji i licencjonowania podmiotów gospodarczych oraz wprowadziła przymus zrzeszania się w stowarzyszeniach branżowych. Przepisy dotyczące stosunków pracy zostały zawarte w rozdziale VI o nazwie „pomocnicza służba przemysłowa (Gewerblisches Hilfspersonale)". Ustawodawca zaliczył do służbobiorców, pozostających $\mathrm{w}$ takich samych stosunkach służbowych $\mathrm{w}$ ramach działalności przemysłowej pomocników-robotników fabrycznych, pomocnice- kobiety oraz czeladników zatrudnionych w warsztatach rzemieślniczych

18 Reichs-Gesetz- Blatt für das Kaiserthum Österreich (dalej: RGBL), 1859, nr 227. M. Kallas, M. Krzymkowski, Historia ustroju i prawa, s. 431-433. 
i pracowników (tzw. kupczyków) przedsiębiorstw handlowych. Ustawodawca utrzymał zasadę swobodnego kształtowania stosunków pracy. Paragraf 75 wskazywał na zasadnicze elementy stosunku pracy, jak „sposób użycia pomocnika, jego płaca i całe zresztą stanowisko, czas trwania służby, czas próby $w$ danym razie i okres wypowiedzenia są przedmiotem dobrowolnej umowy. W braku takowej przypuszcza się, że płaca ma być tygodniową a termin wypowiedzenia dwutygodniowy, pod innymi zaś względami zwyczaj miejscowy służy za prawidło". Wynikające z przepisu prawo zobowiązań miało charakter swobodnego kształtowania umów z pracownikami, przy dopuszczeniu zwyczaju w poszczególnych przedsiębiorstwach, a nawet w branżach. Pracodawcy otrzymali także wsparcie $\mathrm{w}$ zakresie organizacji tygodnia pracy. Został oficjalnie wprowadzony zakaz obchodzenia dowolnych świąt oraz przymus pracy $w$ poniedziałek. Pracownik mógł wykonywać pracę jedynie za zezwoleniem pracodawcy, w określonym przez niego czasie. Ze względu na wysoki poziom niezadowolenia grup pracowniczych został potwierdzony zakaz zmowy pracowniczej mającej na celu odmowę świadczenia pracy lub użycia innych środków służących wymuszaniu lepszych warunków płacy i pracy. Ustawa przemysłowa szczegółowo określała w paragrafie 78 sytuacje, w jakich można było rozwiązać stosunek pracy bez wypowiedzenia. Pracodawca miał prawo rozwiązać umowę, gdy pracownik:

a) okazał się niezdolny do pracy;

b) dopuścił się czynu, w wyniku którego utracił zaufanie przełożonych;

c) trudnił się bez zezwolenia ubocznym zajęciem, które utrudnia mu wykonywanie obowiązków pracowniczych;

d) nieudolnie wykonywał obowiązki, podburzał współpracowników, uczniów do nieposłuszeństwa, do stawiania czynnego oporu wobec pracodawcy lub dopuścił się innego czynu naruszającego dobre imię pracodawcy;

e) z własnej winy wprowadził się w stan niezdolności do pracy lub był niezdolny do pracy dłużej niż cztery tygodnie;

f) był uwięziony dłużej niż osiem dni.

Pracownik miał prawo zerwać umowę, gdy:

a) nie mógł pracować ze względu na pogarszający się stan zdrowia;

b) pracodawca dopuścił się czynnej obelgi, poniżył pracownika;

c) pracodawca nakłaniał go do czynów nieetycznych, niezgodnych z prawem; 
d) pracodawca naruszał warunki umowy, wstrzymuje wypłatę należnych świadczeń;

e) przedsiębiorstwo upadło lub $z$ innych powodów pracownik nie może liczyć na zatrudnienie i płacę.

W przypadku niezgodnego z prawem rozwiązania stosunku pracy przez pracodawcę, pracownik miał prawo do umówionego lub zwyczajowego wynagrodzenia wynikającego $z$ okresu wypowiedzenia. Jeżeli zaś pracownik porzucił pracę przed uzgodnionym terminem, wówczas pracodawca mógł zmusić go w drodze przymusu administracyjnego do powrotu do pracy, a także miał prawo do ukarania takiego pracownika zgodnie $z$ istniejącym zwyczajem. Ustawa wprowadziła obowiązek posiadania tzw. książki robotniczej, którą wydawały urzędy gminne właściwe dla miejsca zamieszkania pracownika, w których zatrudniający mieli obowiązek potwierdzania zatrudnienia. Książka robotnicza, jako forma legitymacji, była dokumentem, który podlegał kontroli przez policję. Poza tym nałożyła na przedsiębiorców zatrudniających powyżej 20 pracowników obowiązek prowadzenia rejestru pracowników, w którym znajdowały się podstawowe dane, jak imię i nazwisko, wiek, miejsce urodzenia, rodzaj zatrudnienia i wysokość poborów. Rejestr pracowników podlegał kontroli władz administracyjnych. Pracodawcy ponadto mieli obowiązek opracowania regulaminu pracy i zakresu obowiązków pracowników, które miały być wywieszone w miejscach widocznych w warsztatach i halach fabrycznych. W przypadku zatrudniania kobiet i dzieci istniał wymóg opracowania odrębnych zakresów czynności, z uwzględnieniem możliwości wykorzystania siły fizycznej kobiet i dzieci, w przypadku tych ostatnich uwzględnienia godzin nauki szkolnej. Ogólnie dostępna informacja miała zawierać:

- liczbę godzin pracy;

- zrozumiały sposób obliczania wynagrodzenia za przepracowane godziny;

- prawa przysługujące nadzorcom w pracy;

- wyjaśnienie, w jakiej sytuacji znajdzie się pracownik, gdy zachoruje lub ulegnie nieszczęśliwemu wypadkowi;

- wielkości dyscyplinarnych kar pieniężnych oraz dodatkowych potrąceń na inne cele;

- okres wypowiedzenia i przypadki, w jakich pracownik może zwolnić się z pracy; 
Takie informacje miały być także dostępne dla władz kontrolujących zakłady pracy. W przypadku zakładów przemysłowych zatrudniających dużą liczbę robotników ustawodawca w zakresie problematyki socjalnej, mając na względzie zapewnienie im wsparcia w przypadku chorób i nieszczęśliwych wypadków zobowiązał pracodawców do tworzenia kas chorych. Robotnicy mieli też prawo przystąpienia do innych kas chorych, działających na danym terenie. Ustawa przemysłowa szczegółowo regulowała kwestę zatrudnienia dzieci. Wprowadzała zakaz zatrudniania w zakładach przemysłowych dzieci poniżej 10 roku życia. Paragraf 86 stwierdzał, że „dzieci od 10 do 12 lat można jedynie używać za okazaniem pozwolenia wydanego od przełożonego gminy na podanie ojca lub opiekuna i to do takich robót, które nie są szkodliwe zdrowiu i nie tamują rozwinięcia sił fizycznych. Pozwolenie może być wtedy tylko wydanym, jeżeli zatrudnienie w zakładzie przemysłowym nie stoi na przeszkodzie odwiedzaniu szkoły pospolitej, lub jeżeli przedsiębiorca urządził osobną szkołę, w której dzieci dostatecznie kształcone być mogą według przepisów władzy szkolnej". Z kolei paragraf 87 omawiał sprawę zatrudniania starszych dzieci, do 14 roku życia, których czas pracy został określony na 10 godzin dziennie, zaś „od 14 do 16 lat dziennie najwyżej 12 i to z odpowiednim rozkładem na czas spoczynku. Po godzinie 9-tej z wieczora i przed 5-tą z rana nie można używać dzieci nie mających jeszcze lat 16 . W takich atoli zakładach przemysłowych, gdzie dzień i noc robota idzie, a bez czego ruch roboczy doznałby szkody, władza może dozwolić, aby dzieci nie mające jeszcze lat 16, wszelako liczące już lat 14, mogły być użytymi do pracy nocnej, pod warunkiem jednak stosownej przemiany dniem i nocą. Również w przypadkach nadzwyczajnej potrzeby zwierzchności może dozwolić chwilowego przedłużenia czasu roboczego o 2 godziny dla robotników nie mających jeszcze 16 lat, wszelako na czas nie dłuższy nad czterotygodniowy".

Przyjęte przez Austrię regulacje były dalekie od tych, które wprowadzano w niektórych państwach. Na przykład robotnicy australijscy już w $1856 \mathrm{r}$. wywalczyli sobie ośmiogodzinny dzień pracy, bez zmniejszenia dotychczasowego wynagrodzenia. Przepisy zawarte w ustawie przemysłowej z 20 XII 1859 r. dotyczące stosunków pracy obowiązywały w następnych dekadach, w których coraz silniej w Austrii pomimo prześladowań rozwijał się ruch związkowy i socjalistyczny. Po krótkim okresie liberalizmu gospodarczego, konserwatywna koalicja dużych właścicieli ziemskich i przedsiębiorców powstrzymywała się z reformami, oczekiwanymi przez środowiska pracownicze. 
Poważniejsze zmiany w zakresie bezpieczeństwa i higieny pracy zaszły w latach osiemdziesiątych XIX w., podczas długoletniego urzędowania premiera hrabiego Edwarda Taaffe. Władze administracyjne dążyły do wzmocnienia nadzoru nad przedsiębiorstwami. Na mocy ustawy z 17 VI 1883 r. został utworzony podległy ministrowi handlu Centralny Inspektorat Przemysłowy („Zentral Gewerbe Inspektorat”) i okręgowe inspektoraty przemysłowe ${ }^{19}$. W ramach zadań inspektorów przemysłowych dotyczących praw pracowniczych zgodnie z paragrafem 5 ustawy należało dbanie o przestrzeganie przepisów w zakresie:

1. środków i urządzeń, które przedsiębiorcy przemysłowi byli zobowiązani wprowadzić dla ochrony zdrowia i życia robotników;

2. czasu pracy i przerw w pracy na odpoczynek;

3. prowadzenia spisów robotników, regulaminów organizacji pracy, wypłat;

4. zawodowego kształcenia pracowników młodocianych.

Okręgowe inspektoraty przemysłowe prowadziły także działalność mającą na celu upowszechnianie znajomości przepisów ustawy przemysłowej wśród właścicieli i kadry kierowniczej zakładów, w zakresie bezpieczeństwa i higieny pracy. Starsi inspektorzy przemysłowi, inspektorzy przemysłowi lub komisarze inspekcji przemysłowej mieli obowiązek opiniowania warunków pracy w tworzących się lub przekształcanych zakładach produkcyjnych. W 1885 r. na terenie monarchii habsburskiej działało kilkunastu urzędników państwowych kontrolujących zakłady przemysłowe (tym samym czasie w Anglii było 55 inspektorów fabrycznych). W Austrii Dolnej na 60000 zakładów było dwóch inspektorów, po jednym w Austrii Górnej i w Salzburgu na około 28000 zakładów, czterech inspektorów w Czechach na około 125000 zakładów, na Morawach i na Śląsku trzech inspektorów na ponad 56000 zakładów, po jednym inspektorze w Galicji i na Bukowinie na 38000 zakładów ${ }^{20}$. Z czasem liczba urzędników się zwiększała. W 1906 r. po raz pierwszy $\mathrm{w}$ inspektoracie przemysłowym $\mathrm{w}$ Wiedniu pracowała kobieta Alice Ritter. W 1918 r., przed rozpadem monarchii, w austriackich inspektoratach przemysłowych pracowało pięć kobiet. Na początku XX w. na terenie Przedlitawii istniało 31 okręgów inspekcji przemysłowej. W Galicji działały okręgowe C.K. Inspektoraty Przemysłowe („k.k. Gewerbe-Inspektion”) we

19 DzUP, 1883, nr 117.

20125 Jahre Arbeitsinspektion in Österreich, s. 19. 
Lwowie, Krakowie i w Stanisławowie ${ }^{21}$. Od 1911 r. w części austriackiej monarchii były już 42 okręgi inspekcyjne, w tym w nowoutworzony Przemyślu.

Warunki pracy w wielu zakładach przemysłowych budziły zastrzeżenia inspektorów przemysłowych. Zagrożenie zdrowia robotników, między innymi w rozwijającej się branży chemicznej dostrzegała także C.K. Najwyższa Rada Zdrowia. Na jej wniosek ministerstwo spraw wewnętrznych i handlu wydało rozporządzenie 17 I $1885 \mathrm{r}^{22}$, które wprowadzało zabezpieczenie pracowników w przedsiębiorstwach produkujących zapałki, gdzie w procesie produkcji używano fosfor. Rozporządzenie wprowadzało nakaz ścisłego nadzoru lekarskiego w zakładach oraz częstych zmian robotników, szczególnie pracujących przy przygotowywaniu tzw. „papki fosforowej” oraz w suszarniach, ze względu na masowe choroby uzębienia i martwicy kości szczękowych. Przedsiębiorca miał obowiązek zabezpieczyć ubrania ochronne oraz „Winien postarać się o dostateczną ilość miednic i naczyń na wodę i czuwać nad tym, aby robotnicy, zanim się zabiorą do jedzenia, lub się oddalą z fabryki, umyli sobie twarz i ręce i wypłukali usta czystą wodą"23. Rozporządzenie miało być wywieszone w widocznym miejscu na terenie zakładów pracy. Niezastosowanie się przedsiębiorcy do przepisów zawartych w rozporządzeniu groziło sankcjami zawartymi w ustawie karnej.

Ważnym aktem prawnym $\mathrm{w}$ zakresie bezpieczeństwa i higieny pracy tzw. pomocników młodocianych i kobiet zatrudnionych w górnictwie była ustawa z 21 VI $1884 \mathrm{r}^{24}$ Wprowadziła ona zakaz zatrudniania przy pracach wydobywczych pod ziemią dzieci poniżej 14 roku życia. Na powierzchni przy lekkich pracach na prośbę rodziców lub opiekunów, w wyjątkowych sytuacjach ustawodawca dopuścił możliwość zatrudnienia dzieci w wieku od 12 do 14 lat, pod warunkiem realizowania obowiązku szkolnego. Dziewczęta i kobiety również nie mogły pracować przy pracach wydobywczych pod ziemią. Mogły pracować jedynie na powierzchni. Po porodzie mogły wrócić do pracy po sześciu tygodniach, ale po okazaniu zaświadczenia lekarskiego o zdolności do pracy po czterech tygodniach. Obowiązywał zakaz pracy w niedzielę, chociaż ustawa dopuszczała prace porządkowe czy konserwacyjne. Bardzo ogólny paragraf 4 ustawy z 21 VI 1884 r. dawał możliwość

21 DzUP, 1903, nr 144.

22 Tamże, 1885, nr 8.

23 Tamże.

24 Tamże, 1884, nr 115. 
w praktyce wykonywania $\mathrm{w}$ niedzielę szeregu prac na powierzchni, włącznie $z$ załadunkiem i przygotowaniem soli lub węgla do transportu. Szychta w kopalniach dla młodocianych i kobiet została określona na 12 godzin, w tym dwie godziny obowiązkowych przerw na odpoczynek. W kopalniach położonych w wyższych partiach Alp minister rolnictwa miał prawo dopuścić do innej organizacji czasu pracy, jednak i w takiej sytuacji tydzień pracy nie mógł być dłuższy niż 60 godzin. Ustawodawca wprowadził aż pięcioletni okres przejściowy dla wdrożenia dziewcząt i kobiet w nowe, mniej uciążliwe obowiązki w kopalniach, zachowując w tym czasie prawo zatrudniania ich przy czynnościach zwyczajowo im dotychczas przydzielanych. Nad przestrzeganiem przepisów w kopalniach miały czuwać starostwa górnicze. Za niewdrożenie w życie przepisów ustawy groziła grzywna do 200 florenów.

Premier Edward von Taaffe mimo oporu konserwatystów w Radzie Państwa znowelizował ustawę przemysłową w latach 1883 i 1885. Ustawa z 8 III $1885 \mathrm{r} .^{25}$ częściowo zmieniła zapisy w rozdziale VI, które dotyczył pracowników przemysłowych. Na mocy paragrafu 75 została zakazana praca w niedziele. W uzasadnionych przypadkach, ze względu na proces technologiczny lub potrzeby rynkowe, minister handlu w porozumieniu z ministrem spraw wewnętrznych oraz ministrem wyznań i oświecenia publicznego miał prawo wydać zgodę na pracę w niedzielę. Rozporządzenie ministerialne wydane $\mathrm{w}$ tej sprawie $27 \mathrm{~V} 1885 \mathrm{r}$. dopuszczało pracę $\mathrm{w}$ niedzielę $\mathrm{w}$ wielu gałęziach przemysłu, usług i handlu. Między innymi w: hutach żelaza; zakładach produkujących naczynia emaliowane; walcowniach stali, miedzi, mosiądzu; fabrykach budowy maszyn i urządzeń; hutach szkła; garbarniach; zakładach drukarskich; fabrykach papieru; młynach; cukrowniach i zakładach produkujących syrop i cukier gronowy; palarniach kawy; browarach; gorzelniach; zakładach produkujących chemikalia, sztuczny lód, ocet, margarynę; w rafineriach. Na mocy rozporządzenia w niedziele mogły pracować sklepy i firmy handlowe, piekarnie, cukiernie, rzeźnie, zakłady fryzjerskie i fotograficzne; sklepy z pamiątkami i lombardy; przedsiębiorstwa przewozowe, zakłady pogrzebowe $^{26}$. Kolejne paragrafy 78, 78a, 78b znowelizowanej ustawy przemysłowej wprowadzały zakaz zmuszania robotników oraz członków ich rodzin do zakupu towarów w wyznaczonych sklepach oraz dokonywania wypłat pieniężnych w gospodach i wyszynkach. Ustawodawca utrzymał obowiązkowy

\footnotetext{
25 Tamże, 1885, nr 22.

26 Tamże, nr 83.
} 
dokument, tzw. książkę robotniczą, którą wydawały urzędy gminne. Książką robotnicza dokumentowała przebieg zatrudnienia. Na prośbę pracownika pracodawca miał obowiązek wpisać opinię o pracy (świadectwo pracy) ${ }^{27}$. Należy wskazać na paragraf 87 , który dawał możliwość powołania na terenie powiatu Rady Polubownej, mogących rozstrzygać spory pomiędzy przedsiębiorcami niezrzeszonymi a pracownikami. Właściwość Rad Polubownych nie dotyczyła spraw wynikających z kompetencji sądów przemysłowych powołanych w Austrii na mocy ustawy z 14 V 1869 r. ${ }^{28}$ Ustawa z 8 III 1885 r. wprowadziła zakaz zatrudniania dzieci do 12 roku życia. W sprawie zatrudniania tzw. pomocników młodocianych (w rozumieniu ustawy pomocnik młodociany to osoba, która nie ukończyła 16 roku życia) paragraf 94 głosił, że „między 12 a skończonym 14 rokiem życia wolno używać do regularnych zajęć przemysłowych, o ile praca taka nie szkodzi ich zdrowiu i nie tamuje fizycznego rozwoju a zarazem nie stoi na przeszkodzie dopełnianiu ustawowego obowiązku uczęszczania do szkoły". Praca pomocników młodocianych nie mogła trwać dłużej niż osiem godzin dziennie. Podobny zapis w paragrafie 96b obowiązywał wobec pomocników młodocianych od 14 do 16 roku życia. Pracowników młodocianych i kobiet nie wolno było zatrudniać w godzinach nocnych. W przypadku kobiet, które urodziły dzieci ustawa zakazywała kierowania ich do zajęć produkcyjnych przed upływem czterech tygodni po porodzie. Ważną zmianę wprowadzał paragraf 96a. Mianowicie ograniczył on czas pracy dorosłych robotników do 11 godzin dziennie. Jednak jeżeli „wypadki żywiołowe lub nieszczęścia przerwały fabrykację regularną albo jeżeli zaszła potrzeba zwiększenia pracy władza przemysłowa pierwszej instancji może poszczególnym przedsiębiorstwom przemysłowym pozwolić czasowe przedłużenie pracy". Za przepracowane godziny nadliczbowe należała się dodatkowa zapłata. Należy uznać, że ustawa z 8 III 1885 r. była krokiem na drodze poprawy stosunków pracy w monarchii habsburskiej, to jednak wydane na podstawie zawartych w niej przepisów szczegółowe rozporządzenia w dużym stopniu zachowały dotychczasowe zachowawcze podejście do stosunków pracy w przedsiębiorstwach przemysłowych i handlowych.

27 Wzory nowych, obszernych 40-stronnicowych książek robotniczych dla dorosłych i młodocianych pomocników przemysłowych zostały określone rozporządzeniem ministrów handlu i spraw wewnętrznych z 12 V 1885 r. Tamże, nr 69.

${ }^{28}$ RGBL, 1869, nr 63. 
Pośród wydanych przez ministra handlu w porozumieniu z ministrem spraw wewnętrznych aktów normatywnych wydanych na podstawie szczegółowego upoważnienia zawartego w ustawie przemysłowej należy wskazać na dwa rozporządzenia z $27 \mathrm{~V} 1885$ r., które umożliwiały zatrudnianie pracowników młodocianych w nocy w niektórych zakładach przemysłowych ${ }^{29}$. Pracownicy młodociani płci męskiej do ukończenia 16 roku życia mogli pracować w zakładach produkujących kosy, w przędzalniach jedwabiu, wełny, bawełny, lnu oraz w hutach. Dziewczęta do 16 roku życia mogły pracować w nocy przy czyszczeniu pierza pościelowego, przy apreturze (impregnacji) materiałów oraz produkcji ozdobnych koronek maszynowych. Dziewczęta mogły pracować do 22.00 godziny w zakładach szyjących czapki i kapelusze. Poza tym pracę nocną mogły wykonywać w cukrowniach i w zakładach produkujących wyroby mięsne w formie konserw. Spoza branży przemysłowej pracę do godziny 24.00 mógł wykonywać młodociany kelner w restauracjach i gospodach. Ograniczenie pracy dzieci i młodzieży było postulatem postępowej inteligencji austriackiej. W marcu 1907 r. odbył się w Wiedniu Pierwszy Austriacki Kongres Ochrony Dzieci, którego obrady zdominowała dyskusja na temat zatrudniania i warunków pracy dzieci. Także podczas obrad Drugiego Austriackiego Kongresu Ochrony Dzieci, który się odbył we wrześniu 1913 r. w Salzburgu temat pracy dzieci był najważniejszy. Zasadniczym postulatem uczestników kongresu (nauczycieli, dyrektorów szkół, powiatowych i okręgowych inspektorów szkolnych) było ograniczenie zatrudniania dzieci i zwiększenia ich udziału w procesie edukacji.

Podstawą prawną mocy prawnej kolejnego rozporządzenia także z $27 \mathrm{~V}$ 1885 r. był paragraf 96a ustawy przemysłowej zezwalający na przedłużenie dnia pracy o jedną godzinę $\mathrm{w}$ niektórych zakładach przemysłowych o ruchu ciągłym ${ }^{30}$. I tak 12-godzinny dzień pracy nadal obowiązywał w zakładach rozmotywowania i przędzenia jedwabiu, przędzalniach wełny, bawełny, lnu i konopi, młynach, zakładach chemicznych, drukarniach, hutach, cementowniach, cegielniach, fabrykach papieru, cukrowniach, browarach, gorzelniach, fabrykach octu (z wyjątkiem zakładów produkujących ocet winny), zakładach produkcji drożdży, lodu sztucznego. W drodze rozporządzeń w monarchii habsburskiej został utrzymany 12-godzinny dzień pracy w większości zakładów przemysłowych. Poza tym należy podkreślić, że

29 DzUP, 1885, nr 84, nr 86.

30 Tamże, nr 85. 
przyjęte w aktach normatywnych zakazy w zakresie bezpieczeństwa i higieny pracy były często łamane. Szybki przyrost miejsc pracy w przemyśle na przełomie XIX i XX w. powodował określone problemy. W zakładach przemysłowych wzrastała liczba pracujących kobiet. Tzw. „kobiety fabryczne” pracowały za mniejsze stawki niż mężczyźni. Dlatego pośród postulatów ruchu kobiecego zgłoszonych podczas obchodów pierwszego austriackiego Dnia Kobiet w 1911 r. obok żądania ośmiogodzinnego dnia pracy, ustalenia płacy minimalnej, poprawy warunków w zakresie bezpieczeństwa i higieny pracy był także postulat zrównania płac z mężczyznami za taką samą pracę. W realiach gospodarki austriackiej przedsiębiorcy nastawieni na zysk generalnie wypłacali robotnikom niskie pensje, szczególnie tam, gdzie ruch związkowy nie istniał lub był zbyt słaby.

Na początku XX w. coraz poważniejszy problemem stanowiły przestarzałe obiekty fabryczne i brak wymaganych urządzeń, które poprawiłyby standardy bezpieczeństwa i higieny pracy. W efekcie na terenie Przedlitawii dochodziło do dużej liczby wypadków przy pracy i chorób zawodowych wśród robotników. W pierwszej kolejności minister spraw wewnętrznych rozporządzeniem z 20 VII $1894 \mathrm{r}^{31}$ wprowadził obowiązkowe ubezpieczenia robotników oraz klasy czynności niebezpiecznych w poszczególnych zakładach pracy. Ryzyko wypadku przy wykonywaniu czynności zawodowych oraz wysoka zachorowalność wśród robotników wynikała także z niewłaściwego zabezpieczenia maszyn i urządzeń oraz nieprzystosowania obiektów fabrycznych do wymogów ochrony zdrowia i higieny pracy. Aby to zmienić kierownik ministerstwa handlu $\mathrm{w}$ porozumieniu $\mathrm{z}$ ministrem spraw wewnętrznych w oparciu o paragraf 74 ustawy przemysłowej z 8 III 1885 r., wydał 23 XI 1905 r. rozporządzenie „o ochronie życia i zdrowia robotników pomocniczych"32. W 106 punktach rozporządzenia zostały zawarte wymogi i zalecenia, jakie powinny spełniać nowoczesne obiekty fabryczne oraz działające w nich urządzenia i maszyny. Wprowadzone standardy bezpieczeństwa i higieny pracy robotników w znacznej części wynikały z obowiązujących w państwie ogólnych przepisów budowlanych i sanitarnych. Rozporządzenie zaczęło obowiązywać od 1 I 1906 r. Skierowane do przedsiębiorców przepisy, mające na celu poprawę warunków bezpieczeństwa i higieny pracy,

\footnotetext{
31 Tamże 1894, nr 167. Ubezpieczenia dobrowolne w przemyśle zostały wprowadzone na mocy ustawy z 28 grudnia 1887 roku. Tamże, 1888, nr 1.

${ }_{32}$ Tamże, 1905, nr 176.
} 
w rzadkich przypadkach wywołały szybkie działania. Proces modernizacji zakładów przemysłowych napotykał na opór organów właścicielskich, często był rozłożony na lata. Niemniej ewolucyjny postęp w zakresie tworzonej gałęzi prawa, prawa pracy był w konsekwencji traktowany jako czynnik modernizacyjny $\mathrm{w}$ austriackiej gospodarce i w ramach doktryny istotnym elementem regulacji ram na rynku pracy.

W końcu XIX w. regulacja prawa pracy stała się w monarchii habsburskiej zasadniczym elementem dążeń politycznych sił lewicowych. Wzrost znaczenia związków zawodowych (pierwszy kongres związków zawodowych odbył się w Wiedniu w grudniu 1893 r.) i ogólnoaustriackiej partii socjaldemokratycznej z Victorem Adlerem na czele, stawiał kwestię robotniczą w rzędzie najważniejszych problemów społecznych, które powinny zostać rozwiązane na drodze legislacyjnej. Kształtująca się doktryna w zakresie prawa pracy w znacznym stopniu była wypadkową grup nacisku, właścicieli przedsiębiorstw i nurtu lewicowego. Po nowelizacji ordynacji wyborczej do Rady Państwa i wprowadzeniu piątej kurii wyborczej, od 1897 r. w realnej polityce austriackiej pojawili się posłowie socjaldemokratyczni. W ostatnich kilkunastu latach istnienia monarchii habsburskiej, w okresach kryzysów gospodarczych, kwestia zabezpieczenia pracowników najemnych była często podnoszona w Radzie Państwa. Jednocześnie częściej dochodziło do strajków, które były ważnym instrumentem walki o poprawę warunków pracy i płacy. Podstawową kwestią stało się dążenie do ograniczenia godzin pracy. Już podczas oficjalnych obchodów 1 maja 1890 roku głównym postulatem był ośmiogodzinny dzień pracy. Do świadomości społecznej coraz bardziej docierało hasło „osiem godzin pracy, osiem godzin rekreacji, osiem godzin snu". Około 1910 r. w wyniku wynegocjowanych układów zbiorowych w części przedsiębiorstwach zaczął obowiązywać dziesięciogodzinny dzień pracy. Postulat ośmiogodzinnego dnia pracy nie został wprowadzony do austriackiego prawa do końca monarchii habsburskiej. Po ogłoszeniu powstania republiki austriackiej 12 X 1918 r., koalicja z udziałem socjaldemokratów przeprowadziła szereg reform w zakresie prawa pracy. Został wprowadzony między innymi ośmiogodzinny dzień pracy, zasiłki dla bezrobotnych i zakaz pracy dzieci. Niemniej dorobek prawodawczy do 1918 r. należy traktować jako ważny wkład w rozwoju nie tylko krajowej, ale także po upadku wielonarodowej monarchii habsburskiej, europejskiej doktryny prawa pracy. 


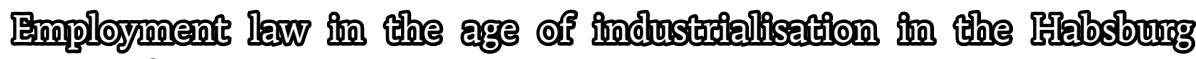 Monareby}

The booming industry was one of the basic factors of the modernisation in nineteenth century. Technological innovativeness was a driving force in the development of the liberal economy, especially in metalworking industry, textiles and mining. The industry substantially influenced the development of the cities, where the industrial plants were established. This period saw an increase in the population of the cities due to contract work, which enabled people to earn their living. The industrial revolution changed the structure of the employment in the economy of England, France, Belgium and other countries of Western Europe. Besides economic sphere, it influenced social circumstances, the politics and culture. In Austria, this process was less impetuous. The Habsburg Monarchy was the country where the industrialisation processes did not happen on a large scale or cause major transfigurations in economic relations. Until the end of the multinational monarchy, the Austrian economy preserved the agrarian character, although the modernisation of the economic structures was developing in nineteenth century.

Translated by: Ryszard Tomczyk 